\title{
Development and Characterization of Desmoglein-3 Specific T Cells from Patients with Pemphigus Vulgaris
}

\author{
Mong-Shang Lin, ${ }^{\star}$ Sue J. Swartz, ${ }^{\star}$ Argelia Lopez, ${ }^{\star}$ Xiang Ding, ${ }^{\star}$ Marcelo A. Fernandez-Vina, ${ }^{\S}$ Peter Stastny, ${ }^{\S}$ Janet A. Fairley, \\ and Luis A. Diaz ${ }^{\star \ddagger}$ \\ *Department of Dermatology, Medical College of Wisconsin, and the ${ }^{\ddagger}$ VA Medical Center, Milwaukee, Wisconsin 53226; and ${ }^{\S}$ Department \\ of Internal Medicine, University of Texas Southwestern Medical Center, Dallas, Texas 75235
}

\begin{abstract}
Pemphigus vulgaris (PV) is a cutaneous autoimmune disease characterized by blister formation in the suprabasilar layers of skin and mucosae and anti-desmoglein-3 (Dsg3) autoantibodies bound to the surface of lesional keratinocytes and circulating in the serum of patients. This disease can be reproduced in neonatal mice by passive transfer of patients' IgG, indicating that humoral immunity plays an important role in the pathogenesis of PV. Currently, the role of $T$ lymphocytes in the development of $\mathrm{PV}$ is not clear. Here, we report that three immunoreactive segments of the ectodomain of Dsg3 specifically induced proliferation of $\mathrm{T}$ cells from $\mathrm{PV}$ patients. We found that $\mathrm{T}$ lymphocytes from 13 out of 14 patients responded to at least one of three Dsg3 peptides. $T$ cells from controls and other patient groups did not respond to these Dsg3 peptides. The major T cell population stimulated by these Dsg3 peptides was CD4 positive. Dsg3-specific $\mathrm{T}$ cell lines and clones were developed and were shown to express a CD4 positive memory T cell phenotype. Upon stimulation, these cell lines and clones secreted a Th2-like cytokine profile. The Dsg3 responses of these $T$ cells were restricted to HLA-DR, and not -DQ and -DP, of the major histocompatibility complex. This information will help to elucidate the cellular immune abnormalities leading to production of pathogenic IgG autoantibodies in patients with PV. (J. Clin. Invest. 1997. 99:31-40.) Key words: pemphigus vulgaris • desmoglein-3 • T lymphocytes • MHC II restriction • cytokines
\end{abstract}

\section{Introduction}

T lymphocytes play a major role in the regulation and induction of specific immune responses against infectious agents that are foreign to the host. T cells are also crucial in keeping the immune system from reacting against self antigens. The inability to regulate or control the reactivity of $T$ cells to self antigens can lead to the initiation and the development of autoimmune diseases.

Address correspondence to Mong-Shang Lin, Ph.D., 4075 MACC Fund Research Center, 8701 Watertown Plank Road, Milwaukee, WI 53226. Phone: 414-456-8183; FAX: 414-266-8673; E-mail: mslin@ post.its.mcw.edu

Received for publication 4 September 1996 and accepted in revised form 24 October 1996.

J. Clin. Invest.

(C) The American Society for Clinical Investigation, Inc.

0021-9738/97/01/0031/10 \$2.00

Volume 99, Number 1, January 1997, 31-40
Pemphigus vulgaris $(\mathrm{PV})^{1}$ is an autoimmune skin disease characterized by intraepithelial blisters on the skin and mucous membranes and pathogenic antiepithelial autoantibodies which recognize the desmosomal glycoprotein desmoglein-3 (Dsg3) (1-3). The blisters in PV are located in the suprabasilar regions of the epidermis (4) and are formed by a process of keratinocyte cell-cell detachment known as acantholysis $(1,4)$. The anti-Dsg3 autoantibodies in PV are bound to lesional epidermis in vivo and also circulate in the serum of the patients (2). The serum titers of these autoantibodies correlate with disease extent and activity. Several groups have reported that the autoantibody response in $\mathrm{PV}$ is polyclonal and predominantly of the IgG4 subclass (5-7), although IgG1 autoantibodies have been detected early in the disease (6). The IgG fractions from sera of PV patients are pathogenic by passive transfer experiments, i.e., when injected intraperitoneally into neonatal BALB/c mice, they reproduce the clinical, histological, and immunological features of the human disease in these animals, indicating that PV autoantibodies play an important role in the pathogenesis of this disease (8).

The target antigen recognized by PV autoantibodies is Dsg3, a 130-kD glycoprotein that belongs to the cadherin superfamily of cell adhesion molecules $(9,10)$. Dsg3 is a transmembrane protein localized in the desmosome (11), a structure that is involved in epidermal cell-cell adhesion and, hence, in maintaining the structural integrity of the epidermis. The intracellular domain of Dsg3 appears to interact with a desmosomal plaque component, plakoglobin, linking it to the cytoskeleton, whereas the extracellular domain mediates homophilic interactions that bring about cell adhesion $(10,12)$. It is the ectodomain of Dsg3 that bears the epitopes that are recognized by pathogenic autoantibodies from the sera of PV patients $(13,14)$.

Although the relevance of anti-Dsg3 autoantibodies in PV is well defined, the cellular immune mechanisms involved in autoantibody formation, i.e., $\mathrm{T}$ and $\mathrm{B}$ cell interactions, are mostly unknown. T cells have been implicated in autoimmune diseases such as multiple sclerosis (15), myasthenia gravis (16), and Graves' disease (17). Disease-specific T lymphocytes from these patients have been shown to recognize self antigens and participate in the initiation or progression of the respective autoimmune disease. Antibody production by B cells requires the participation of T helper (Th) cells in T cell-dependent antibody responses (18-22). During an antigen-driven activation of $\mathrm{T}$ cells, they are induced to secrete lymphokines that are crucial in antibody production and Ig isotype switching by $\mathrm{B}$

1. Abbreviations used in this paper: APC, antigen-presenting cells; $\mathrm{BP}$, bullous pemphigoid; CP, cicatricial pemphigoid; Dsg, desmoglein; GST, glutathione-S-transferase; IF, immunofluorescent; PF, pemphigus foliaceus; $\mathrm{PV}$, pemphigus vulgaris; SI, stimulation index. 
cells. Since PV is an autoimmune disease mediated by autoantibodies, it is postulated that $\mathrm{T}$ lymphocytes participate in the pathogenesis of this disease in the stages leading to the production of pathogenic autoantibodies.

The purpose of this study was to investigate the response of T lymphocytes from PV patients to Dsg3 fusion proteins and to define the properties of Dsg3-specific T cells. In this paper, three segments of the ectodomain of Dsg3 that specifically induce proliferation of $\mathrm{T}$ cells from PV patients were identified. Moreover, only the CD4, but not the CD8, population of $\mathrm{T}$ lymphocytes proliferated in response to Dsg3. The Dsg3-specific $\mathrm{T}$ cell lines and clones derived from PV patients maintained antigen specificity in culture. The recognition of Dsg3 epitopes by these $\mathrm{T}$ cell clones was restricted to HLA-DR. Dsg3-specific T cells expressed a CD4 memory T cell phenotype and a Th2-like cytokine profile. These findings suggest that CD4 positive T lymphocytes and the Th2 cytokine profile of these cells may modulate the pathogenic autoantibody response in PV patients.

\section{Methods}

PV patients and controls. Sera and PBMC were obtained from $14 \mathrm{PV}$ patients. These 14 patients fulfilled the clinical, histologic, and immunofluorescent (IF) criteria of PV and were followed at the dermatology departments of the Medical College of Wisconsin and the University of Cincinnati. All PV patients showed PV autoantibody titers as determined by indirect IF against human skin and monkey esophagus substrates. Patients with other cutaneous autoimmune diseases such as pemphigus foliaceus (PF) $(n=6)$, bullous pemphigoid (BP) $(n=3)$, cicatricial pemphigoid $(\mathrm{CP})(n=2)$, and psoriasis $(n=4)$ were included along with normal volunteers $(n=8)$ as controls.

Antibodies and cell lines. Antibody-producing hybridoma cell lines OKT3 (anti-CD3), OKT4 (anti-CD4), OKT8 (anti-CD8), and 7G7B6 (anti-IL-2 receptor [anti-IL-2r]) were purchased from American Type Culture Collection (Rockville, MD). These antibodies were purified from mouse ascites by protein $\mathrm{G}$ chromatography. The IL-6 sensitive cell line B9 (23) was a generous gift from Dr. Luciden Aardon (Central Laboratory of the Netherlands). This cell line was cultured in 10\% FBS RPMI 1640 medium supplemented with $50 \mathrm{U} / \mathrm{ml}$ of IL-6 (Biosource International, Camarillo, CA). The IL-2/IL-4 sensitive cell line HT-2 was obtained from Dr. Robert Fritz (Department of Microbiology, Medical College of Wisconsin) and cultured in $10 \%$ FBS RPMI 1640 medium containing $20 \mathrm{U} / \mathrm{ml}$ of human recombinant IL-2 (rIL-2). The human rIL-2 was purified from a baculovirus vector system (24). Anti-IL-4 (11B11) antibodies were purified from hybridoma cell culture supernatants by protein $\mathrm{G}$ affinity chromatography and dialyzed against PBS. Rat IgG, the control antibody for 11B11, was purchased from Sigma Chemical Co. (St. Louis, MO). AntiTCR $\alpha / \beta-1$, anti-HLA-DQ (Leu-10), and -DP were purchased from Becton-Dickinson (San Jose, CA). The anti-HLA-DQ antibody used in this study recognizes a common polymorphic epitope present on HLA-DQ molecules of cells expressing DQw1 and DQw3 (usually associated with DR1, DR2, DR4, DR5, DRw8, DRw9, and DRw10) and absent from DQw2 (usually associated with DR3 and DR7). The anti-HLA-DP antibody used in our experiments recognizes cells expressing DP1, DP2, DP3, DP4, and DP5. Anti-CD45RA, anti-CD19, and fluorescein-labeled goat $\mathrm{F}\left(\mathrm{ab}^{\prime}\right)_{2}$ anti-mouse Ig were purchased from Biosource International. Anti-CD45RO and anti-HLA-DR (clone B-F1) antibodies were purchased from Immunotech (Westbrook, ME). Negative control antibodies mouse IgG2a and IgG1 were obtained from DAKO (Produktionsvej, Denmark).

Preparation of Dsg3 fusion proteins. The Dsg3 fusion proteins used in this study are shown in Fig. 1. Five Dsg3 fusion proteins were prepared encompassing the following segments: A (amino acids [AA] 145-192), B (AA 240-303), C (AA 570-614), D (AA 760-793), and E (AA 794-827). Peptides A, B, and C represent segments of the ectodomain and $\mathrm{D}$ and $\mathrm{E}$ represent the intracellular domain of Dsg3. Control fusion proteins include glutathione- $S$-transferase (GST) and the $\mathrm{S} \Delta 1$ peptide which encompasses 48 amino acids of the BP180 ectodomain. The BP180 antigen is a hemidesmosomal protein recognized by BP autoantibodies (25). All fusion proteins were soluble in commonly used buffers. Briefly, the fusion proteins were derived by subcloning PCR products of Dsg3 into the $3^{\prime}$ end of the Schistosoma japonicum GST gene in the prokaryotic expression vector, pGEX-2T (Pharmacia LKB Biotechnology, Piscataway, NJ) as described previously (25). Recombinant proteins encoded by the series of Dsg3 expression constructs were expressed in Escherichia coli strain DH5 $\alpha$ and purified by glutathione-agarose affinity chromatography (26). These fusion proteins were dialyzed against PBS, concentrated by ultrafiltration, and filter-sterilized. The protein concentration was determined by Bradford protein assays (Bio-Rad, Hercules, CA).

Isolation of $P B M C$ and purification of $C D 4$ and $C D 8$ positive $T$ cells. PBMC were isolated by Ficoll-Hypaque (Pharmacia) density gradient separation (27). T cells were purified by E-rosetting using 2-aminoethylisothiouronium bromide (Sigma)-treated sheep red blood cells (Colorado Serum Co., Denver, CO) (28). CD4 ${ }^{+}$or $\mathrm{CD} 8^{+}$ $\mathrm{T}$ lymphocytes were further negatively selected from the total $\mathrm{T}$ cell population by a magnetic sorter (Miltenyi Biotec, Auburn, CA) using anti-CD8 or anti-CD4 antibodies, respectively, according to the manufacturer's instructions (29). The purity of isolated cells was $>98 \%$ as determined by flow cytometric analysis (not shown). The purified $\mathrm{T}$ cells were washed with medium three times and resuspended in RPMI 1640 medium supplemented with $10 \%$ human AB serum (NABI, Miami, FL) for the T cell proliferation assays.

$T$ cell proliferation assays. $10^{4}$ purified $\mathrm{T}$ lymphocytes were cultured with $10^{4}$ irradiated $(2,500 \mathrm{rad}) \mathrm{PBMC}$ in the presence of antigens in each well of 96-well U-bottom plates (Corning Co., Oneonta, $\mathrm{NY}$ ) for $7 \mathrm{~d}$. PHA (Sigma) at $0.25 \mu \mathrm{g} / \mathrm{ml}$ or IL-2 at $10 \mathrm{U} / \mathrm{ml}$ served as positive controls in all $\mathrm{T}$ cell proliferation experiments. Cells in each individual well were pulsed with $1 \mu \mathrm{Ci}$ of $\left[{ }^{3} \mathrm{H}\right]$ thymidine (ICN, Costa Mesa, CA) during the last $18 \mathrm{~h}$ of incubation and then harvested by an automated cell harvester (Inotech Biosystems, Lansing, MI). The proliferation of $\mathrm{T}$ cells was determined by measuring the $\left[{ }^{3} \mathrm{H}\right]$ thymidine uptake on a $\beta$-counter (Wallac, Gaithersburg, MD). Data were

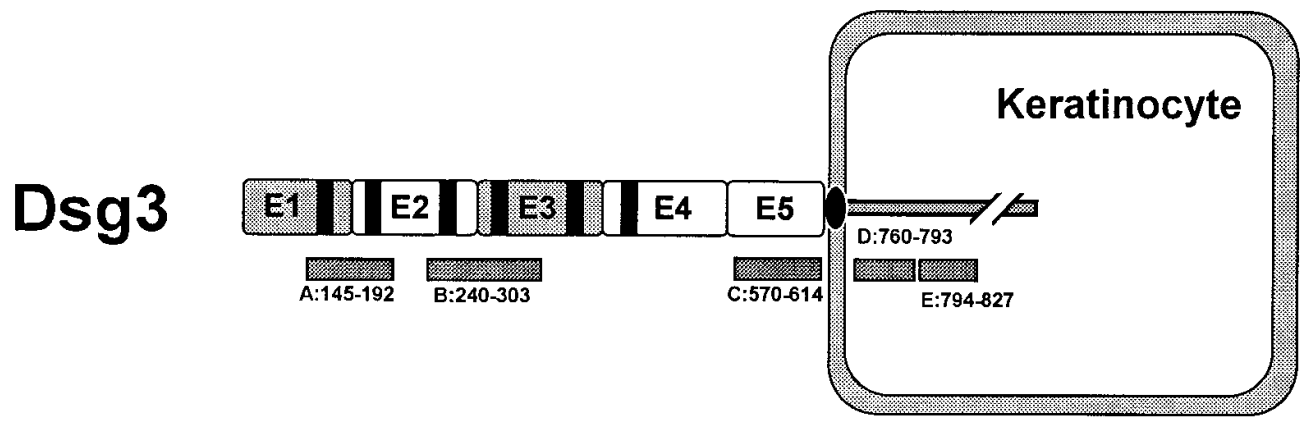

Figure 1. Dsg3 fusion proteins. Dsg3 contains five major cadherin-like domains on the extracellular portion. The black strips are the $\mathrm{Ca}^{2+}$ binding sites. The locations of Dsg3 fusion proteins used in this study are shown as horizontal bars. 
presented as average cpm $\pm \mathrm{SD}$. A stimulation index (SI) (cpm of cells treated with fusion proteins/cpm of cells treated with GST at the same concentration) $\geq 3$ was considered as a positive response.

Development of Dsg3-specific T cell lines and clones from PV patients. PBMCs from PV patients were cultured with $20 \mu \mathrm{g} / \mathrm{ml}$ of Dsg3 fusion proteins at a density of $2 \times 10^{6} / \mathrm{ml}$ in 24-well plates in RPMI 1640 medium supplemented with $10 \%$ human $\mathrm{AB}$ serum for $7 \mathrm{~d}$ at $37^{\circ} \mathrm{C}$. Viable T cells were collected by Ficoll-Hypaque separation and restimulated with $20 \mu \mathrm{g} / \mathrm{ml}$ of Dsg3 antigens in the presence of irradiated autologous PBMC for $7 \mathrm{~d}$. This stimulation procedure was repeated three times. At the last cycle, rIL-2 at the concentration of 10 $\mathrm{U} / \mathrm{ml}$ was added to $\mathrm{T}$ cell cultures $2 \mathrm{~d}$ after antigen stimulation.

The resultant $\mathrm{T}$ cells were cloned by limiting dilution (30) in the presence of $20 \mu \mathrm{g} / \mathrm{ml}$ of antigen, $30 \mathrm{U} / \mathrm{ml}$ of rIL-2, and irradiated autologous PBMC. The T cell lines and clones were maintained by culturing cells with antigen $(20 \mu \mathrm{g} / \mathrm{ml})$ and rIL-2 and restimulated every 7-10 d using irradiated autologous PBMC $\left(2 \times 10^{6} /\right.$ well $)$ and/or EBV-transformed cells (31) as antigen-presenting cells (APC).

Antigen responses and MHC class II restriction of Dsg3-specific T cells. The antigen specificity of derived $\mathrm{T}$ cell lines and clones was examined by culturing $5 \times 10^{4} / \mathrm{ml} \mathrm{T}$ cells with $5 \times 10^{4} / \mathrm{ml}$ of irradiated autologous PBMC in the presence of $20 \mu \mathrm{g} / \mathrm{ml}$ of antigens or with antigen-pulsed EBV-transformed $\mathrm{B}$ cells for $5 \mathrm{~d}$ at $37^{\circ} \mathrm{C}$ in 96 -well plates (final volume $200 \mu \mathrm{l}$ ). T cells in each well were pulsed with 1 $\mu \mathrm{Ci}$ of $\left[{ }^{3} \mathrm{H}\right]$ thymidine during the last $18 \mathrm{~h}$ of incubation. An SI $\geq 3$ was considered as a positive response. PHA at $0.25 \mu \mathrm{g} / \mathrm{ml}$ or IL-2 at $10 \mathrm{U} / \mathrm{ml}$ were used as the positive controls in these proliferation assays.

The MHC class II restriction of antigen responses of PV T cell lines and clones was determined by using anti-HLA-DR, -DQ, and -DP antibodies at concentrations of $1 \mu \mathrm{g} / \mathrm{ml}$ in proliferation assays. Mouse IgG1 was used as a control in these assays. Antibodies were dialyzed against PBS before being used in cell cultures. It was noted that all three antibodies at the concentration used in proliferation assays were documented as sufficient to saturate binding on at least $10^{5}$ APC. The HLA-DR restriction element of Dsg3-specific T cell clones was analyzed further using a panel of EBV-transformed B cell lines expressing different HLA-DRB1 alleles as APC in the T cell proliferation assays. EBV-transformed cells expressing HLA-DRB $1 * 0101$, 0401, 0402, 0405, 0407, 0701, 1401, 1402, and 1501 were used in these experiments.

Surface phenotype of Dsg3-specific T cells. The surface expression of CD3, CD4, CD8, CD19, CD45RA, CD45RO, and TCR $\alpha / \beta$ on Dsg3-specific T cells was examined by flow cytometric analysis using a FACScan ${ }^{\circledR}$ flow cytometer (Becton-Dickinson) and specific monoclonal antibodies. Mouse IgG was used as a negative control. Fluorescein-conjugated goat $\mathrm{F}(\mathrm{ab})_{2}$ anti-mouse Ig was used as the secondary antibody.

Lymphokine profile of Dsg3-specific T cells. $10^{6} \mathrm{~T}$ cells per well were cultured in a 24-well plate in the presence of $10 \mathrm{ng} / \mathrm{ml}$ of PMA (Sigma) and $100 \mathrm{ng} / \mathrm{ml}$ of anti-CD3 antibodies (32). Cell culture supernatants were collected after $30 \mathrm{~h}$ of stimulation, and were subjected to lymphokine bioassays.

The IL- 2 or IL- 4 bioactivities were determined by the proliferation of HT-2 cells (33) as measured by the uptake of $\left[{ }^{3} \mathrm{H}\right]$ thymidine. When IL-2 and/or IL-4 is present in the culture supernatant of activated T cells, the proliferation of HT-2 cells is inhibited by anti-IL-2r or anti-IL-4 antibodies, respectively. For IL-2 and IL-4 assays, 1,000 HT-2 cells in $100 \mu \mathrm{l}$ volume of $10 \%$ FBS medium were seeded in wells of 96-well flat-bottom plates. $10 \mu \mathrm{l}$ of supernatant from activated $\mathrm{T}$ cell cultures and anti-IL-2r, anti-IL-4, or control antibodies at a final concentration of $1 \mu \mathrm{g} / \mathrm{ml}$ were added to each well. The HT-2 cell cultures were allowed to grow for $48 \mathrm{~h}$ and then pulsed with 1 $\mu \mathrm{Ci} /$ well of $\left[{ }^{3} \mathrm{H}\right]$ thymidine during the last $8 \mathrm{~h}$ of incubation.

For IL-6 assays, 5,000 B9 cells were cultured in $100 \mu \mathrm{l}$ with $10 \mu \mathrm{l}$ of supernatants from activated $\mathrm{T}$ cells in 96-well flat-bottom plates for $2 \mathrm{~d}$. Cells in each well were pulsed with $1 \mu \mathrm{Ci}$ of $\left[{ }^{3} \mathrm{H}\right]$ thymidine during the last $8 \mathrm{~h}$ of incubation. The bioactivity of IL-6 was determined by the proliferation of B9 cells.

The presence of $\gamma$-IFN in the activated T cell culture supernatants was determined by an ELISA kit (Genzyme Corp., Cambridge, MA) following the manufacturer's instructions.

MHC class II and ethnic background of PV patients. The analysis of HLA-DRB1 and DQB1 of PV patients was carried out by the use of the sequence specific oligonucleotide hybridization technique of PCR-amplified DNA $(34,35)$. The usage of HLA-DRB1 and DQB1 and ethnic background of PV patients is shown in Table I.

\section{Results}

Responses of PV T lymphocytes to Dsg3 fusion proteins. To examine whether T lymphocytes respond to Dsg3 fusion proteins in proliferation assays, $T$ cells were purified from PBMC of PV patients by E-rosetting. Initial testing of five Dsg3 fusion proteins (described in Methods) to examine the $\mathrm{T}$ cell responses from three PV patients (EG, LS, and RS) revealed that only the three proteins of the Dsg3 ectodomain (A, B, and

Table I. HLA-DR and-DQ Typing, Ethnic Backgrounds, and Dsg3 Responses of Patients with PV

\begin{tabular}{|c|c|c|c|c|c|c|}
\hline Patients & HLA-DR & HLA-DQ & Ethnic background & Dsg3\#145-192 & Dsg3\#240-303 & Dsg3\#517-614 \\
\hline JM & 0402/1401 & $0302 / 0503$ & Slovak & + & + & + \\
\hline RD & $0402 / 1602$ & $0302 / 0502$ & Mexican & - & - & + \\
\hline MP & 0402/1101 & $0302 / 0502$ & Jewish & - & + & + \\
\hline UP & $1404 / 1502$ & 0503/0601 & Indian & + & + & + \\
\hline EG & $0402 / 1401$ & $0302 / 0503$ & Jewish & + & + & + \\
\hline WE & $0402 / 1401$ & $0302 / 0503$ & 1/16 Jewish & + & - & + \\
\hline LB & $0402 / 0402$ & 0302/0302 & Ashkenazi Jewish & - & - & - \\
\hline LS & $0402 / 1302$ & 0302/0604 & Hungarian & + & + & + \\
\hline NW & $1401 / 1401$ & $0503 / 0503$ & Polish & + & + & + \\
\hline RS & $1401 / 1501$ & $0503 / 0602$ & German & - & + & + \\
\hline WAF & 0701/1401 & $0201 / 0503$ & Italian/Croatian & + & + & + \\
\hline MLC & $1401 / 1501$ & $0503 / 0602$ & Dutch & + & + & + \\
\hline $\mathrm{EF}$ & 0301/0701 & 0201/0201 & Jewish & + & + & + \\
\hline ML & ND & ND & Ashkenazi Jewish & + & + & + \\
\hline
\end{tabular}

$N D$, not done; - , no response; +, T lymphocytes proliferate to Dsg3 peptides. 


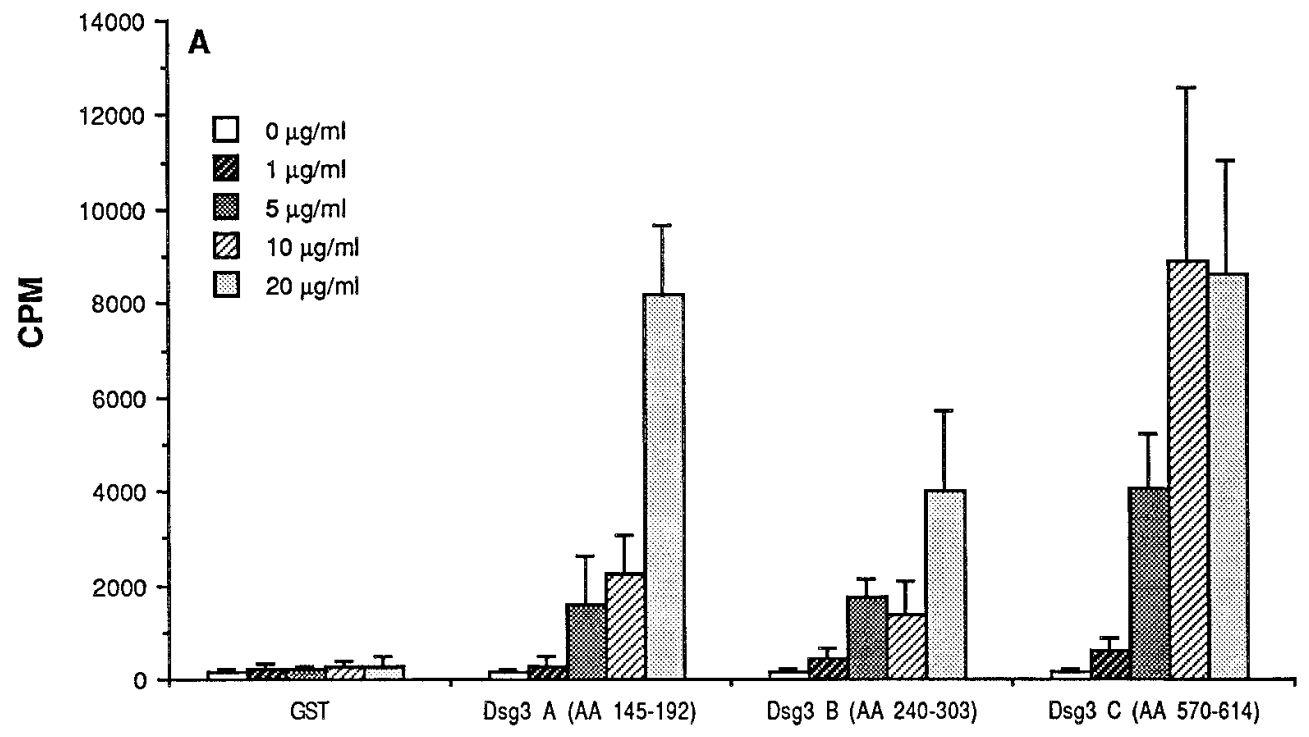

Antigens

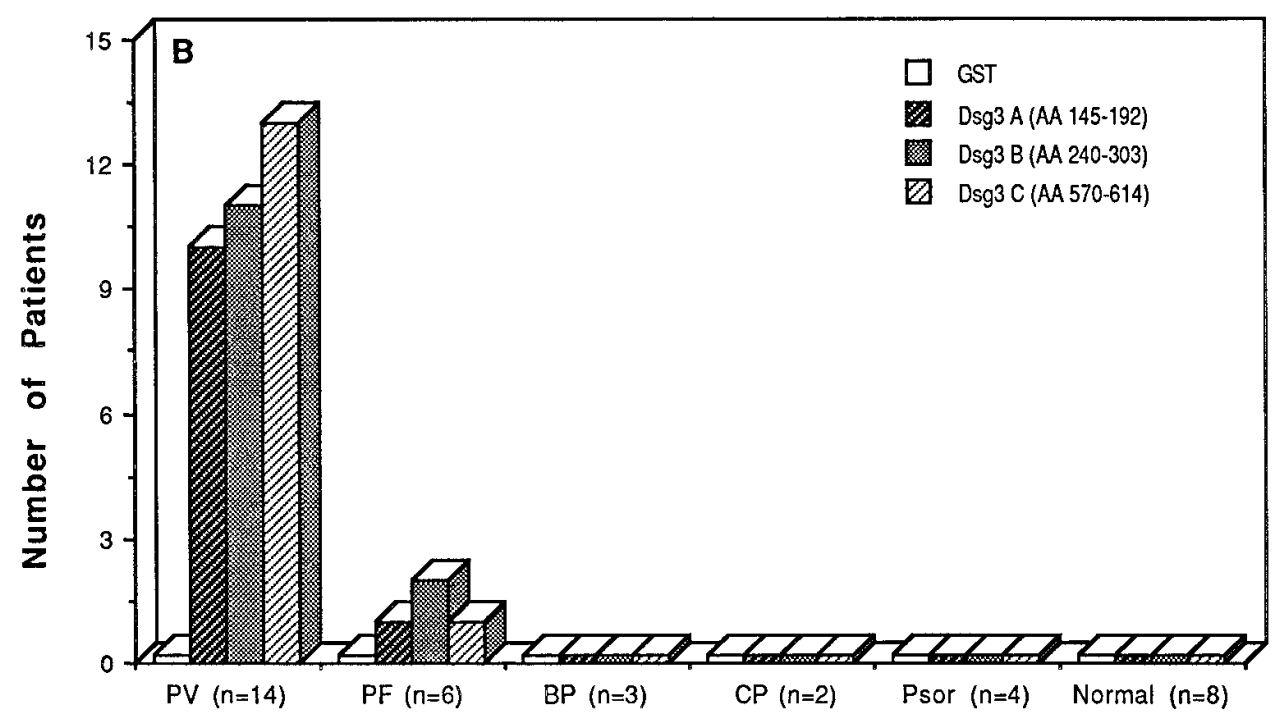

Figure 2. Response of T cells from $\mathrm{PV}$ patients to Dsg3 fusion proteins. The proliferative responses of $\mathrm{T}$ cells from a $\mathrm{PV}$ patient to Dsg3 fusion proteins were examined as described in Methods. T cells from these PV patients responded to these antigens in a dose-dependent manner. GST was used in these experiments as a negative control. Data were expressed as average $\mathrm{cpm} \pm \mathrm{SD}(A)$. T cell responses from patients with $\mathrm{PV}, \mathrm{BP}, \mathrm{CP}$, psoriasis, and healthy controls to Dsg3 fusion proteins were studied. An SI $\geq 3$ was recognized as a positive response $(B)$
C) (Fig. 1) induced proliferation of PV T lymphocytes consistently. The peptides D and E which located in the intracellular domain of Dsg3 do not induce proliferation of T cells from PV patients. As shown in Fig. $2 \mathrm{~A}$, these three immunogenic Dsg3 segments were capable of inducing proliferation of T lymphocytes in a dose-dependent manner. The optimal proliferative response of PV T cells was obtained using an antigen concentration of $20 \mu \mathrm{g} / \mathrm{ml}$. These observations were further extended to a group of $14 \mathrm{PV}$ patients. We found that T cells from $10 \mathrm{pa}-$ tients responded to Dsg3 peptide A (AA 145-192), 11 patients responded to peptide $\mathrm{B}$ (AA 240-303), and 13 patients reacted with peptide C (AA 570-614) (Fig. 2 B and Table I). The stimulatory index of PV T cells to these Dsg3 peptides ranged from 3 to 87 . T cells from only one patient did not respond to any of these Dsg3 peptides. The Dsg3 antigenic response of PV T cells was specific, i.e., these cells were unresponsive to GST antigen and other unrelated epidermal antigens such as $\mathrm{S} \Delta 1$ of the BP180 antigen that were prepared by the same method (not shown). T cells from the control groups, including patients with $\mathrm{BP}(n=3), \mathrm{CP}(n=2)$, and psoriasis $(n=4)$, as well as normal volunteers $(n=8)$, did not respond to any of the Dsg3 fusion proteins (Fig. $2 \mathrm{~B}$ ). Thus, these experiments demonstrate that $\mathrm{T}$ cells from the majority of PV patients specifically respond to one or more Dsg3 fusion proteins. Interestingly, $\mathrm{T}$ cells from two of six PF patients responded to Dsg3 peptide B (AA 240-303), a region of the molecule that shares $~ 52 \%$ homology with Dsg1, the target antigen in PF.

$C D 4^{+} T$ cell population responds to Dsg3 fusion proteins. To further investigate which $\mathrm{T}$ cell population is responsible for Dsg3-induced proliferation, CD4 and CD8 positive T cells were isolated using a magnetic cell sorter and further analyzed using the proliferation assay. As shown in Fig. $3 A, \mathrm{CD}^{+} \mathrm{T}$ cells from a PV patient responded to Dsg3 peptides in a dosedependent manner. $\mathrm{CD}^{+} \mathrm{T}$ cells from $13 \mathrm{PV}$ patients re- 


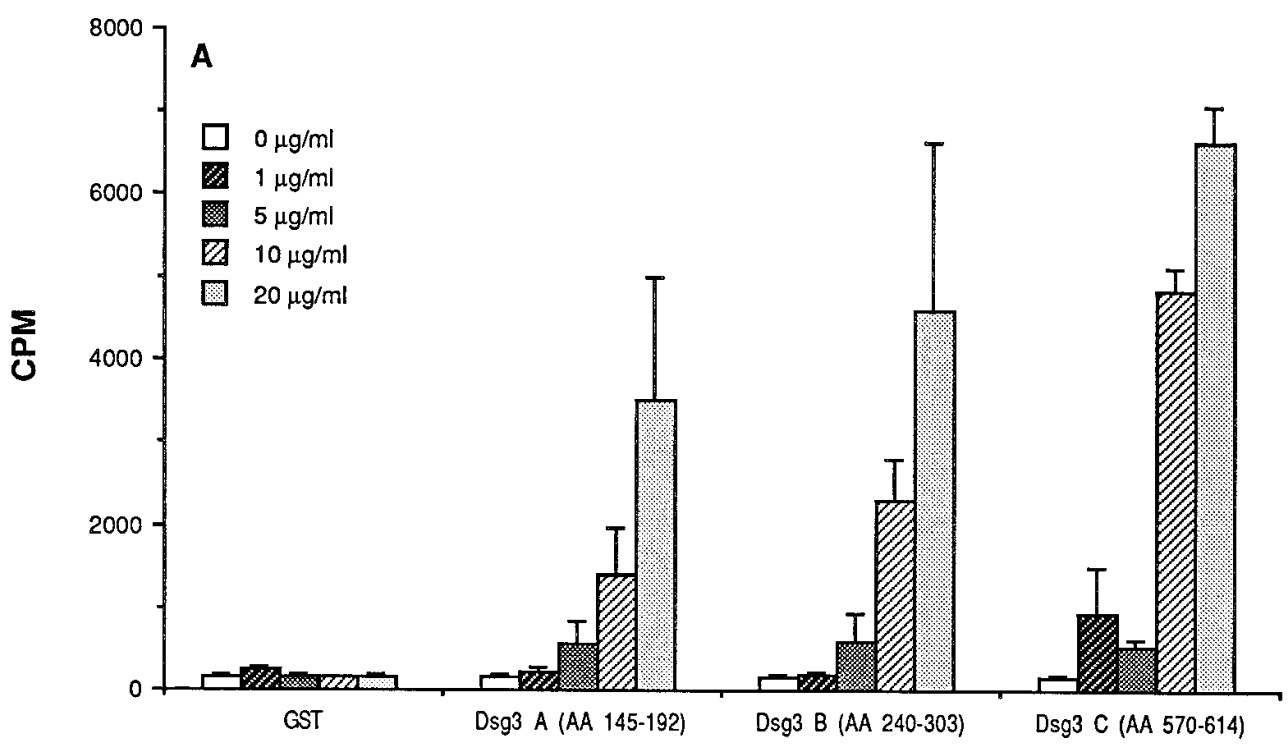

Antigens

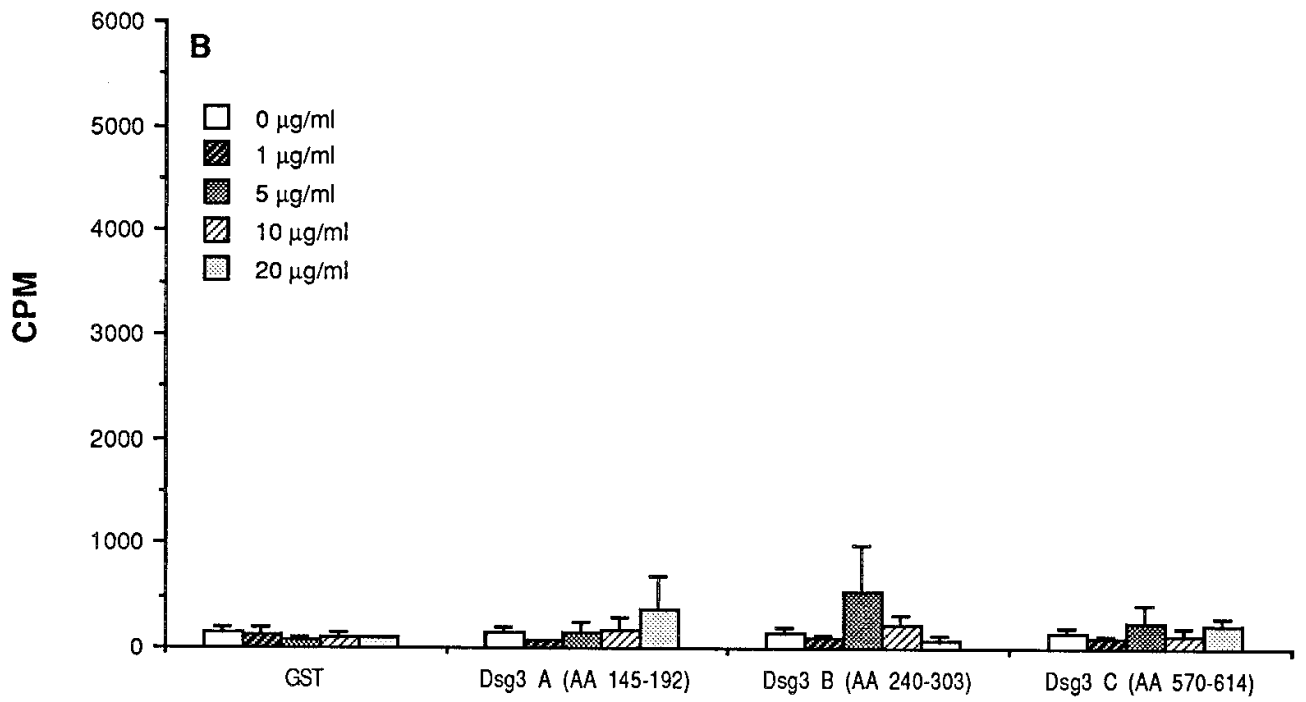

Antigens
Figure 3. $\mathrm{CD}^{+}{ }^{+} \mathrm{T}$ cells involved in the autoimmune response in $\mathrm{PV}$ patients. The response of $\mathrm{CD}^{+}(A)$ and $\mathrm{CD}^{+}(B) \mathrm{T}$ cells to Dsg3 fusion proteins was determined by $\mathrm{T}$ cell proliferation assays as described. Data were expressed as average $\mathrm{cpm} \pm \mathrm{SD}$. sponded to at least one of these $\mathrm{Dsg} 3$ peptides. $\mathrm{CD}^{+} \mathrm{T}$ cells from the same PV patients showed a typical proliferation response to the T cell mitogen PHA and IL-2 (not shown), but failed to proliferate in response to the Dsg3 peptides (Fig. 3 $B) \mathrm{CD}^{+} \mathrm{T}$ cells from all $14 \mathrm{PV}$ patients did not respond to Dsg3 antigens. These results strongly suggest that CD4 positive $\mathrm{T}$ lymphocytes are the major $\mathrm{T}$ cell population involved in the autoimmune responses in these patients.

Antigen specificity of Dsg3-specific T cell lines and clones. To study the properties of Dsg3-specific T lymphocytes, antigen-specific $\mathrm{T}$ cell lines were generated from four PV patients (MLC, WAF, EG, and NW) using the three immunoreactive Dsg3 fusion proteins listed above. T cell clones were subsequently derived from cell lines by limiting dilution. The antigen specificity of these T cell lines and clones to Dsg3 peptides was confirmed by the proliferation assay. As shown in Fig. 4,
WAF-1 and WAF-2, two T cell clones developed from a PV patient, specifically responded to the Dsg3 peptide originally used to derive these clones but did not proliferate with other Dsg3 fusion proteins. Similarly, T cell lines and clones derived from other PV patients also specifically responded to the Dsg3 fusion proteins that had been originally used to derive the antigen-specific T cells (SI $=4-135)$. These results demonstrate that PV T cell clones maintain their antigen specificity in vitro.

MHC II restriction of Dsg3-specific T cells. To investigate the MHC II restriction of Dsg3-specific responses of T cell clones developed from PV patients, anti-HLA-DR, -DQ, and -DP antibodies were introduced in $\mathrm{T}$ cell proliferation assays. Nonspecific mouse IgG1 was used as an isotype control. As demonstrated in Fig. $5 A$, only the anti-DR antibody, but not anti-DQ or -DP antibodies, inhibited the proliferation response of Dsg3-specific $\mathrm{T}$ cell clones to recombinant Dsg3 


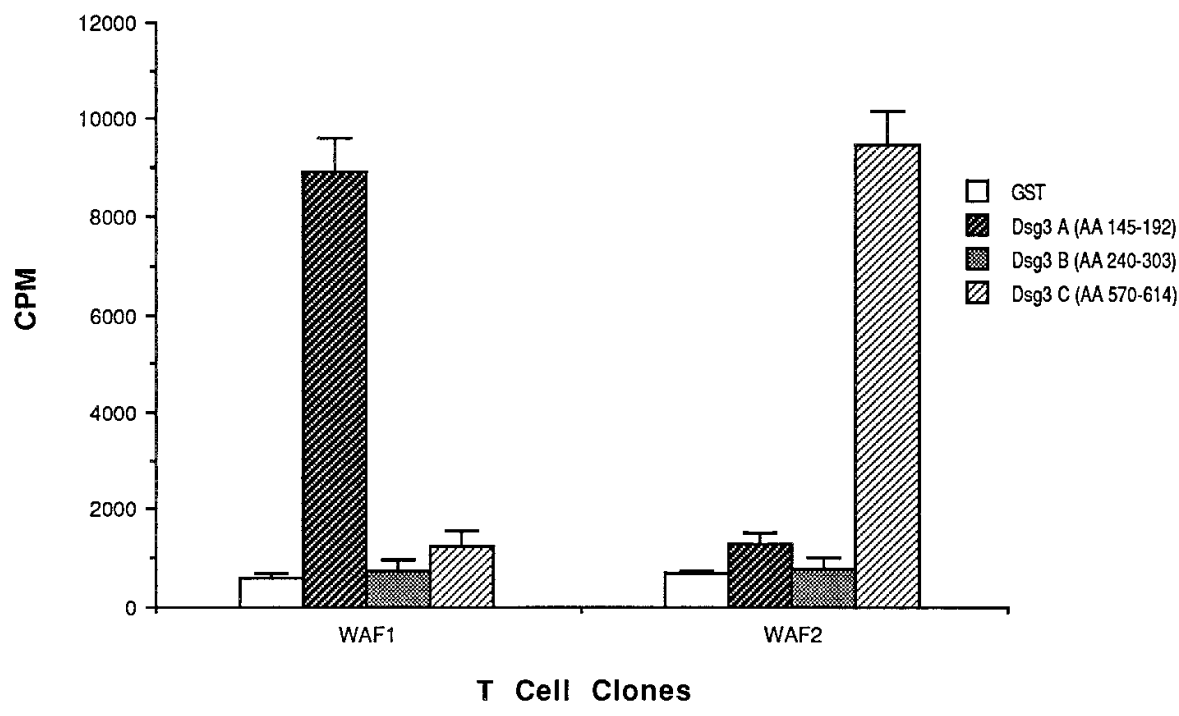

Figure 4. Dsg3-specific T cell clones respond to Dsg3 fusion proteins. The antigen specificity of T cell clones WAF1 and WAF2 which were developed from a PV patient was examined by proliferation assays. Data shown here were expressed as average $\mathrm{cpm} \pm \mathrm{SD}$.

peptides, indicating that the recognition of Dsg3 by PV T cells is restricted to HLA-DR. In five individual Dsg3-specific clones and two cell lines that were tested, all exhibited antigen responses restricted to HLA-DR. Anti-HLA-DQ antibodies in some experiments partially blocked Dsg3-induced $\mathrm{T}$ cell proliferation $(<10 \%)$; however, this degree of inhibition was far lower than that induced by anti-DR antibodies. To examine which DR allele is the restricted element for Dsg3 antigen presentation, proliferation of T cell clone WAF1 was examined using a panel of EBV-transformed cells as APCs. As shown in Fig. $5 \mathrm{~B}$, Dsg3-pulsed APCs expressing either DRB1*1401 or DRB1*0402 were effective in activating this T cell clone, suggesting that both alleles may be important for autoimmune T cell responses in PV.

Cell surface phenotype and cytokine profile of Dsg3-specific T cells. Flow cytometric analysis was used to determine the cell surface phenotypes of the Dsg3-specific T cells. As shown in Fig. 6, EG3.20, a representative Dsg3-specific T cell clone, expressed CD3, CD4, CD45RO, and TcR $\alpha / \beta$, but was negative for CD8, CD45RA, and the B cell marker CD19. This result shows that Dsg3-specific $\mathrm{T}$ lymphocytes carry a CD4 memory T cell phenotype. Other Dsg3-specific T cell lines and clones from PV patients exhibited the same phenotype (not shown).

The cytokine profile of the Dsg3-specific T cells was determined as follows. T cells were activated by anti-CD3 antibodies in the presence of PMA for $30 \mathrm{~h}$. The activity of IL-2, IL-4, IL-6, and $\gamma$-IFN in the T cell culture supernatants was then examined by cytokine bioassays or the ELISA method. As summarized in Table II, Dsg3-specific T cell clones secrete IL-4 and IL-6, but not IL-2 and $\gamma$-IFN, suggesting that these T cells express a Th2-like lymphokine profile.

\section{Discussion}

This investigation demonstrates that $\mathrm{T}$ cells from PV patients proliferate when incubated with antigenic peptides derived from the extracellular domain of Dsg3 presented by autologous APCs. The T cells of only one patient (LB), out of the 14 tested, failed to respond to any of the Dsg3 peptides. This patient was receiving high doses of steroids and immunosuppres- sive therapy at the time her cells were obtained for analysis. Since the Dsg3 peptides were prepared as bacterial GST fusion proteins, it was important to test GST for T cell proliferative activity. $\mathrm{T}$ cells from $\mathrm{PV}$ patients remained unreactive when incubated with GST or GST conjugated to other unrelated epidermal-derived antigens, such as S $\Delta 1$ of the BP180 antigen (25). The PV T cell proliferative response to Dsg3 fusion proteins was dose dependent. The control group, which included $\mathrm{T}$ cells from three BP patients, two cases of $\mathrm{CP}$, four cases of psoriasis, and eight healthy individuals, did not proliferate when incubated with these Dsg3 fusion proteins. It was noted that T cells from two PF patients $(n=6)$ also responded to Dsg3 peptide B (AA 204-303). It appears likely that a subpopulation of $\mathrm{T}$ cells from certain $\mathrm{PF}$ patients may recognize epitopes within this region of Dsg3 due to the high degree of sequence identity (52\%) between Dsg3 and Dsg1 (the PF antigen) at the level of the peptide.

This study showed that $\mathrm{T}$ cells from the majority of PV patients recognize peptide C (AA 570-614) of the Dsg3, suggesting that this region of the molecule may contain epitopes that

Table II. Cytokine Profile of Dsg3-specific T Cell Lines and Clones

\begin{tabular}{llccc}
\hline & IL-2 & IL-4 & IL-6 & $\gamma$-IFN \\
\hline T cell lines & & & & \\
EG3 & Undetectable & $5.2 \pm 0.2$ & $61.7 \pm 5.4$ & $<3 \mathrm{pg} / \mathrm{ml}$ \\
EG4 & Undetectable & $5.7 \pm 0.5$ & $47.8 \pm 19.6$ & $<3 \mathrm{pg} / \mathrm{ml}$ \\
MLC1 & Undetectable & $8.4 \pm 0.6$ & $18.0 \pm 2.3$ & $<3 \mathrm{pg} / \mathrm{ml}$ \\
NW1 & Undetectable & $13.4 \pm 3.4$ & $17.4 \pm 4.5$ & $<3 \mathrm{pg} / \mathrm{ml}$ \\
& & & & \\
T cell clones & & & & \\
EG3.20 & Undetectable & $59.0 \pm 22.2$ & $53.2 \pm 8.3$ & $<3 \mathrm{pg} / \mathrm{ml}$ \\
EG6.17 & Undetectable & $23.7 \pm 1.5$ & $71.2 \pm 1.2$ & $<3 \mathrm{pg} / \mathrm{ml}$ \\
WAF1 & Undetectable & $6.0 \pm 0.4$ & $21.9 \pm 1.7$ & $<3 \mathrm{pg} / \mathrm{ml}$ \\
WAF2 & Undetectable & $11.5 \pm 4.1$ & $69.5 \pm 0.4$ & $<3 \mathrm{pg} / \mathrm{ml}$ \\
& & & & \\
\hline
\end{tabular}

IL-2, IL-4, and IL-6 were determined by bioassays as described in Methods. Concentrations of IL-4 and IL-6 were expressed as U/ml. $\gamma$-IFN was measured by ELISA. 


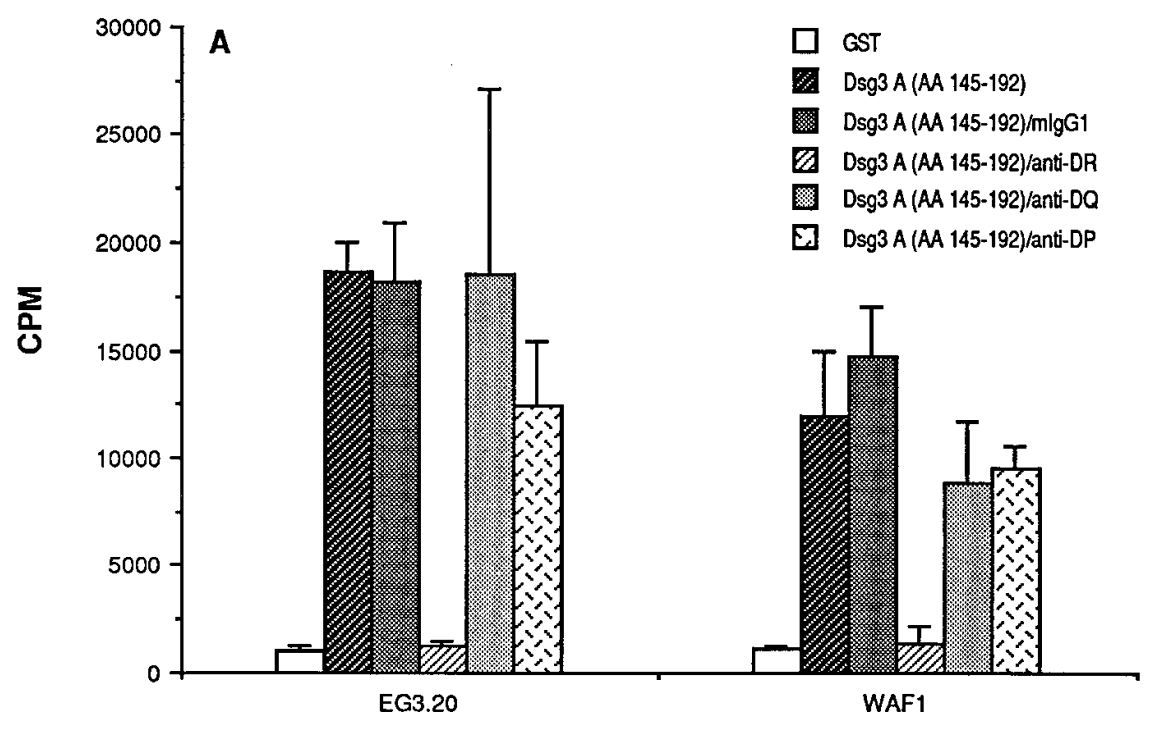

T Cell Clones

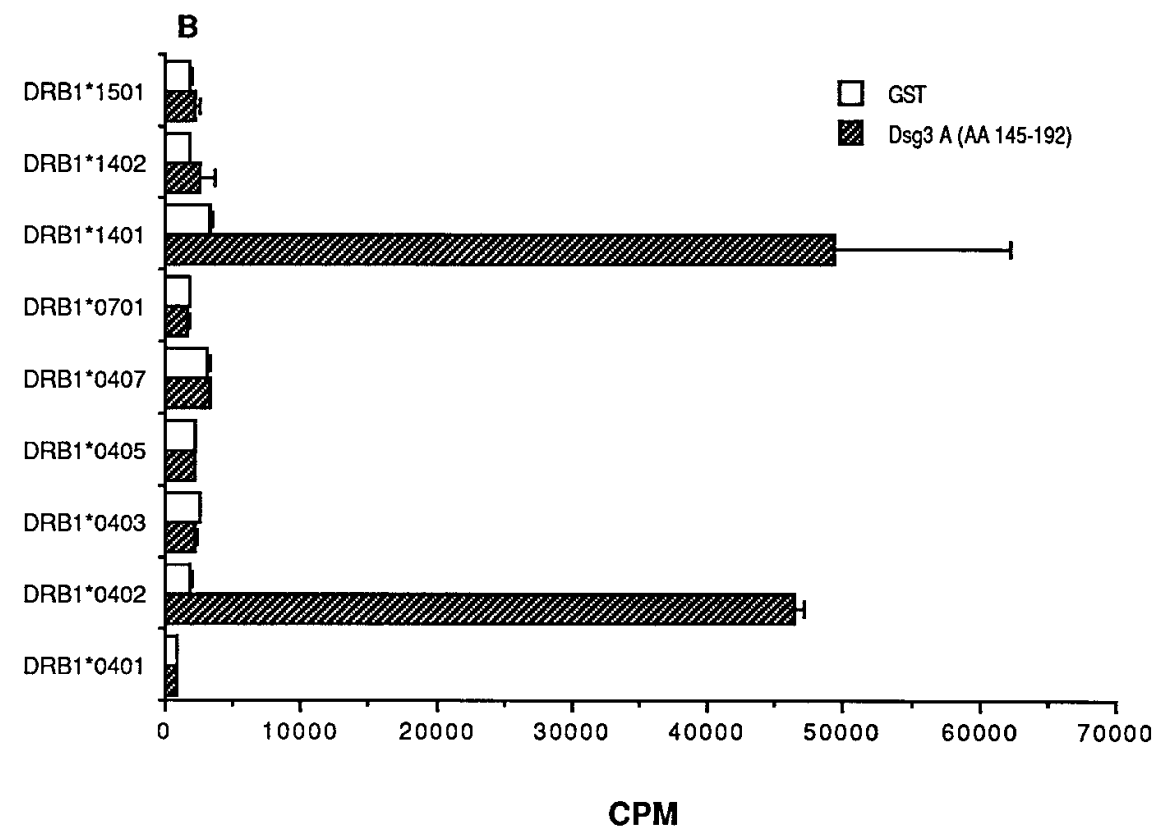

Figure 5. The MHC II restriction of Dsg3specific T cells. The MHC II restriction of responses to Dsg3 fusion proteins in Dsg3specific $\mathrm{T}$ cell clones was investigated by $\mathrm{T}$ cell proliferation assays in the presence of $1 \mu \mathrm{g} / \mathrm{ml}$ of anti-HLA-DR, -DQ, and -DP antibodies. Mouse IgG1 at the same concentration was used as a control. Irradiated autologous PBMC were used as APC in this experiment $(A)$. The response of the Dsg3-specific T cell clone WAF1 to peptide A of Dsg3 (AA 145-192) was examined using a panel of EBV-transformed B cells expressing different HLA-DRB1 alleles as APC in the proliferation assays. The data was displayed as average $\mathrm{cpm} \pm \mathrm{SD}(B)$. are strongly immunogenic. However, in some patients, Dsg3 peptide A (AA 145-192) produced the strongest proliferation response. The diversity of T cell responses to Dsg3 fusion proteins was further demonstrated by the observation that PV patients, although expressing the same or similar MHC class II alleles, respond to different Dsg3 peptides (Table I). It is possible that the initial immune response in PV patients is directed against a single, common epitope on Dsg3 and later spreads to other epitopes located on other domains of the molecule. However, the initial epitope that triggers the autoimmune response in PV patients remains unknown. This "determinant spreading" phenomenon is a consideration in PV, since it has been documented in other autoimmune diseases such as EAE and spontaneous insulin-dependent diabetes in the nonobese diabetic mouse (36-38).
Comparing the sequence of Dsg3 peptides that were used for PV T cell response analysis by Wucherpfennig et al. (39) with the Dsg3 fusion proteins used in this study, we found that only peptide B (AA 204-303) contains a short stretch of complete homology with a peptide used by these investigators (Dsg3\#206-220). Currently, we have derived individual T cell clones responding to different segments of Dsg3 from four PV patients. Each of these T cell clones only responds to the one Dsg3 peptide that had been used to derive the respective clone as shown in Fig. 4. Thus, these results suggest that the T cell response against Dsg3 in PV is polyclonal and represents part of the complex spectrum of PV reactivity to self antigens. It is possible that other regions of Dsg3, which were not included in this study because of the insolubility of the fusion proteins containing these regions (region 1-144, 193-239, 304-569, 615- 

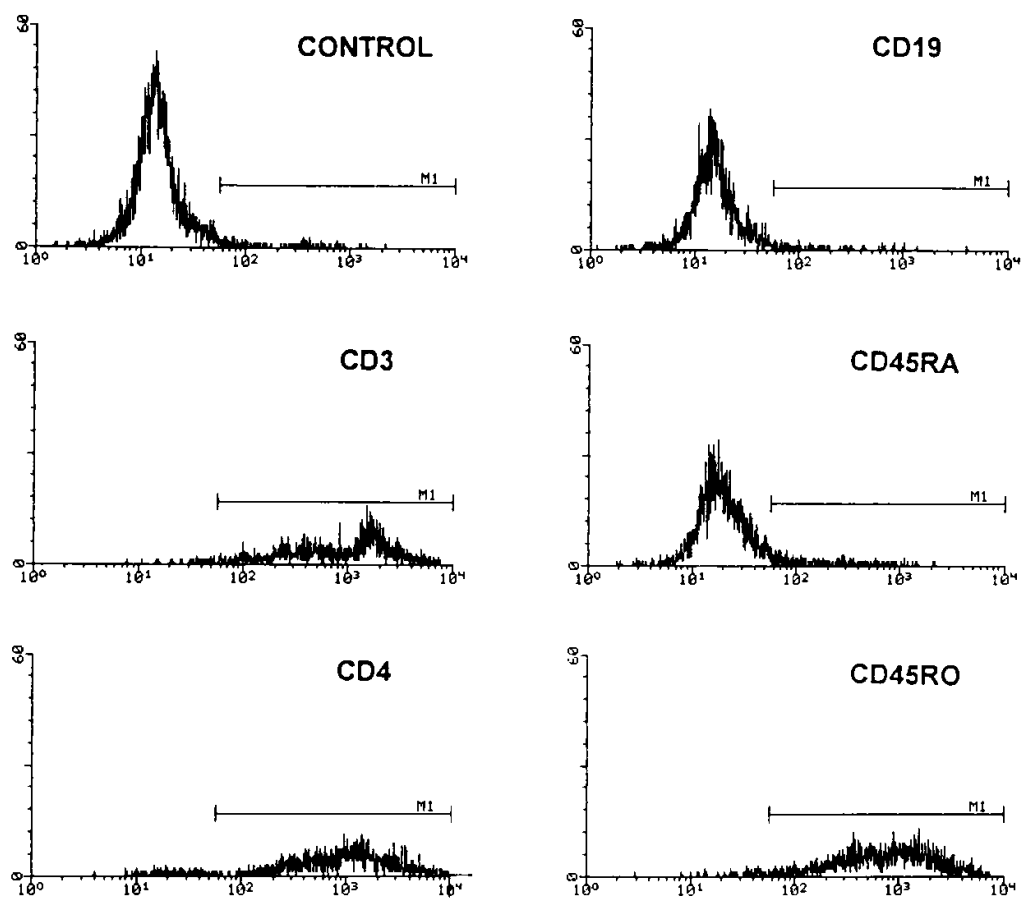

Figure 6. Cell surface phenotype of Dsg3-specific $\mathrm{T}$ cells. The expression of cell markers on the surface of Dsg3-specific $\mathrm{T}$ cells was characterized by flow cyto-
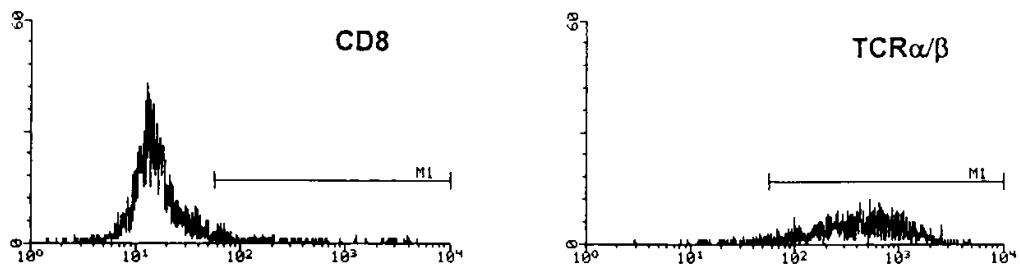
metric analysis using primary monoclonal specific mouse anti-human antibodies as shown. Mouse IgG was used as a control in this experiment. Fluoresceinconjugated goat anti-mouse Ig was used as the secondary antibody. In each histogram, region M1 depicts the population stained positively with primary antibodies. The data of one of the representative $T$ cell clones, EG3.20, were demonstrated in this experiment.

759, and 828-1087), may possess other as yet undisclosed $\mathrm{T}$ cell epitopes that may also be relevant in the pathogenesis of PV. Work is in progress to define epitopes along the whole length of Dsg3.

Although different Dsg3 epitope-specific T cell lines and clones were obtained from PV patients, it is not clear which of the Dsg3 epitopes is responsible for enhancing B cell activation and production of pathogenic anti-Dsg3 autoantibodies. Preliminary testing of the T cell clones specific for the Dsg3 peptide A (AA 145-192) shows that they weakly stimulate autologous B cells in vitro to produce antiepidermal autoantibodies as determined by indirect IF (Lin, M.-S., et al., manuscript in preparation). This encouraging finding suggests that this Dsg3 segment may contain the epitope(s) relevant in the interaction of $\mathrm{T}$ and $\mathrm{B}$ cells in PV. As a following to this observation, overlapping synthetic peptides that cover segment $A$ of Dsg3 were used to map a single 15-amino acid stretch that is responsible of stimulating T cell clones EG3.20 and WAF1.

Contrary to a recent preliminary report, we presented evidence that CD4 positive $\mathrm{T}$ lymphocytes are the major $\mathrm{T}$ cell population responding to Dsg3. This conclusion was supported by the cell surface phenotype of Dsg3-specific T cell lines and clones derived from four patients. These $\mathrm{T}$ cells express a $\mathrm{CD}^{+}$memory $\mathrm{T}$ cell phenotype. The report by Hertl et al. (see reference 50) showed that CD8 positive T lymphocytes from PV patients with the HLA-DR11 haplotype reacted with recombinant Dsg3, suggesting that $\mathrm{CD}^{+} \mathrm{T}$ cells may also participate in the immune response in some PV patients.
The majority of PV patients included in this study exhibit either DRB1*0402 or 1401 or both alleles (Table I). These two DR alleles have strong association with the occurrence of PV in both Jewish and non-Jewish PV populations (40-43). It has been shown that antigenic peptides bound by MHC II molecules are promiscuous in binding to several allotypes (44-46), hence, it is conceivable that the same peptides of Dsg3 are bound by both DRB1 alleles associated with susceptibility to PV and presented to T cells. Interestingly, both DRB1*0402 and DRB1*1401 have glutamic acid and valine at position 71 and 86 , respectively, of the DR $\beta$ subunit. The side chains of these residues have been shown to project into the peptide binding groove and play a crucial role in anchoring the peptides bound (47-49), therefore, suggesting that T cells from PV patients expressing either one of these two alleles may recognize the same Dsg3 peptides. This is in agreement with results reported by Wucherpfennig et al. (39) showing that several antigenic Dsg3 peptides are stimulatory for T cells from PV patients expressing either DRB1*0402 or 1401 alleles. Our results demonstrate unequivocally that $\mathrm{T}$ cells from $\mathrm{PV}$ patients expressing either one of these two DR alleles respond to three Dsg3 peptides (A, B, and C), supporting the notion that both DR haplotypes are important in the presentation of Dsg3 peptides. However, not all $\mathrm{T}$ cells from PV patients expressing these two DR alleles are stimulated by these three peptides, suggesting the autoimmune response to Dsg3 is complex and heterogeneous among PV patients. Similar phenomena have been observed by other investigators (39). 
In this report, we demonstrated that the antigenic response of Dsg3-specific T cells was restricted to HLA-DR. This conclusion was initially drawn by the observation that only the anti-HLA-DR antibody, but not anti-DQ or -DP antibodies, blocks the antigenic response of Dsg3-specific $\mathrm{T}$ cell clones. We found that only EBV-transformed cells expressing the DRB1*0402 or 1401 were capable of presenting Dsg3 fusion proteins to a Dsg3-specific T cell clone WAF1 (Fig. 5 B), further documenting DR restriction in these responses. Interestingly, clone WAF1 was developed from a PV patient expressing DRB1*1401. These results strengthen the hypothesis that both 0402 and 1401 alleles can present the same Dsg3 peptides to PV T cells and that both alleles are the restricting element for $\mathrm{T}$ cell responses to Dsg3 in PV patients. Similar results have been obtained by others (39). However, Hertl et al. (50) showed that the response of Dsg3-specific clones derived from a PV patient expressing HLA-DR11 was restricted to the DQ7 allele rather than to DR11. These seemingly conflicting data indicate that the MHC class II restriction of the Dsg3 presentation may vary from patient to patient in this disease.

The isotype of antibodies produced by a given B cell is dependent on the type of helper $\mathrm{T}$ lymphocytes that it encounters during the T-B cell interaction $(51,52)$. For example, CD4 T cells that secrete Th2 cytokines are capable of inducing B lymphocytes to secrete IgG4 (53). In PV, several groups have demonstrated that $\mathrm{IgG} 4$ is the predominant pathogenic autoantibody fraction, suggesting that $\mathrm{T}$ cells of the $\mathrm{Th} 2$ helper lineage may be relevant in the autoimmune response in these patients (5-7). The findings of this report and those of a previous publication by Wucherpfennig et al. (39) provide strong support for this hypothesis. T cell clones derived from Ashkenazi Jewish PV patients specifically respond to Dsg3 synthetic peptides and secrete IL-4 and IL-10, suggesting that these cells are Th2-like T helper lymphocytes (39). We have further established that our Dsg3-specific T cell clones secrete IL-4 and IL-6, but not IL-2 and $\gamma$-IFN. Since the pathogenic autoantibodies in PV are predominantly of the IgG4 subclass, the Th2-type cytokine profile expressed by autoimmune T cell clones derived from these patients suggests that these $\mathrm{T}$ cells may modulate the $\mathrm{B}$ cell isotype switch in these patients.

\section{Acknowledgments}

The authors thank Dr. Robert Truitt (Department of Pediatrics, Medical College of Wisconsin) and Dr. Robert Fritz (Department of Microbiology, Medical College of Wisconsin) for critical review of the manuscript.

This work was supported in part by U.S. Public Health Service grants R37-AR32081, RO1-AR32599, and T32-AR07577 (L.A. Diaz) and RO1-HL47175 (P. Stastny) from the National Institutes of Health, a Westwood-Squibb Pharmaceutical Dermatology Foundation fellowship (X. Ding), and a Merit Award from the Veterans Administration Central Office (J.A. Fairley and L.A. Diaz).

\section{References}

1. Lever, W.F. 1965. Pemphigus vulgaris. In Pemphigus and Pemphigoid. W.F. Lever, editor. C. Charles Thomas, Springfield.

2. Beutner, E.H., and R.E. Jordon. 1964. Demonstration of skin antibodies in sera of patients with pemphigus vulgaris by indirect immunofluorescent staining. Proc. Soc. Exp. Biol. Med. 117:505-510.

3. Stanley, J.R., L. Koulu, and C. Thivolet. 1984. Distinction between epidermal antigens binding pemphigus vulgaris and pemphigus foliaceus autoantibodies. J. Clin. Invest. 74:313-320.
4. Civatte, A. 1943. Diagnostic histopathologique de la dermatite polymorphe douloureseou maladie de During-Brocq. Ann. Dermatol. Syph. 3:1-30.

5. Jones, C.C., R.G. Hamilton, and R.E. Jordon. 1988. Subclass distribution of human IgG autoantibodies in pemphigus. J. Clin. Immunol. 8:43-49.

6. Bhol, K.A., A. Mohimen, and A.R. Ahmed. 1994. Correlation of subclasses of IgG with disease activity in pemphigus vulgaris. Dermatology (Basel). 189(Suppl. 1):85-89.

7. Bhol, K., K. Natarajan, N. Nagarwalla, A. Mohimen, V. Aoki, and A.R. Ahmed. 1995. Correlation of peptide specificity and IgG subclass with pathogenic and nonpathogenic autoantibodies in pemphigus vulgaris: a model for autoimmunity. Proc. Natl. Acad. Sci. USA. 92:5239-5243.

8. Anhalt, G.J., R.S. Labib, J.J. Voorhees, T.F. Beals, and L.A. Diaz. 1982 Induction of pemphigus in neonatal mice by passive transfer of IgG from patients with the disease. N. Engl. J. Med. 306:1189-1196.

9. Amagai, M., V. Klaus-Kovtun, and J.R. Stanley. 1991. Autoantibodies against a novel epithelial cadherin in pemphigus vulgaris, a disease of cell adhesion. Cell. 67:869-877.

10. Buxton, R.S., and A.I. Magee. 1992. Structure and interactions of desmosomal and other cadherins. Semin. Cell. Biol. 3:157-167.

11. Karpati, S., M. Amagai, R. Prussick, K. Cehrs, and J.R. Stanley. 1993. Pemphigus vulgaris antigen, a desmoglein type of cadherin, is localized within keratinocyte desmosomes. J. Cell Biol. 122:409-415.

12. Amagai, M., S. Karpati, V. Klaus-Kovtun, M.C. Udey, and J.R. Stanley. 1994. Extracellular domain of pemphigus vulgaris antigen (desmoglein 3) mediates weak homophilic adhesion. J. Invest. Dermatol. 102:402-408.

13. Amagai, M., S. Karpati, R. Prussick, V. Klaus-Kovtun, and J.R. Stanley. 1992. Autoantibodies against the amino-terminal cadherin-like binding domain of pemphigus vulgaris antigen are pathogenic. J. Clin. Invest. 90:919-926.

14. Amagai, M., T. Hashimoto, N. Shimizu, and T. Nishikawa. 1994. Absorption of pathogenic autoantibodies by the extracellular domain of pemphigus vulgaris antigen (Dsg3) produced by baculovirus. J. Clin. Invest. 94:59-67.

15. Allegretta, M., J.A. Nicklas, S. Siram, and R.J. Albertini. 1990. T cells responsive to myelin basic protein in patients with multiple sclerosis. Science (Wash. DC). 247:718-721.

16. Melms, A., S. Chrestel, B.C.G. Schalke, H. Wekerle, A. Mauron, M. Ballivet, and T. Barkas. 1989. Autoimmune T lymphocytes in myasthenia gravis. Determination of target epitopes using $\mathrm{T}$ lines and recombinant products of the mouse nicotinic acetylcholine receptor gene. J. Clin. Invest. 83:785790 .

17. Mullins, R.J., S.B. Cohen, L.M. Webb, Y. Chernajovsky, C.M. Dayan, M. Londei, and M. Deldmann. 1995. Identification of thyroid stimulating hormone receptor-specific T cells in Graves' disease thyroid using autoantigentransfected Epstein-Barr virus-transformed B cell lines. J. Clin. Invest. 96:3037.

18. Coffman, R.L., B.W.P. Seymour, D.A. Lebman, D.D. Hiraki, J.A. Christiansen, B. Shrader, H.M. Cherwinski, H.F.J. Savelkoul, F.D. Finkelman, M.W. Bond, and T.R. Mosmann. 1988. The role of helper T cell products in mouse B cell differentiation and isotype regulation. Immunol. Rev. 102:5-28.

19. Bartlett, W.C., A. Michael, J. McCann, D. Yuan, E. Claassen, and R.J. Noelle. 1989. Cognate interactions between helper T cells and B cells. II. Dissection of cognate help by using class II-restricted, antigen-specific, IL-2-dependent helper T cell clone. J. Immunol. 143:1745-1754.

20. Hamano, T., Y. Asano, T. Iwasaki, T. Yamasaki, K. Hase, and E. Kakishita. 1992. Direct interaction between an antigen-specific B cell clones and an MHC class II-reactive helper T cell clone. J. Leukocyte Biol. 52:89-96.

21. Kupfer, A., T.R. Mosmann, and H. Kupfer. 1991. Polarized expression of cytokines in cell conjugates of helper cells and splenic B cells. Proc. Natl. Acad. Sci. USA. 88:775-779.

22. Stevens, T.L., A. Bossie, V.M. Sanders, R. Fernadez-Botran, R.L. Coffman, T.R. Mosmann, and E.S. Vitetta. 1988. Regulation of antibody isotype secretion by subsets of antigen-specific helper T cells. Nature (Lond.). 334:255258

23. Aarden, L.A., E.R. De Groof, O.L. Schapp, and P.M. Lansdorp. 1987. Production of hybridoma growth factor by human monocytes. Eur. J. Immunol. 17:1411-1416.

24. Smith, G.E., G. Ju, B.L. Ericson, J. Mosohera, H.W. Lahm, R. Chizzonite, and M.D. Summers. 1985. Modification and secretion of human interleukin 2 produced in insect cells by a baculovirus expression vector. Proc. Natl. Acad. Sci. USA. 82:8404-8408.

25. Liu, Z., L.A. Diaz, S.J. Swartz, J.L. Troy, J.A. Fairley, and G.J. Giudice. 1995. Molecular mapping of a pathogenically relevant BP180 epitope associated with experimentally induced murine bullous pemphigoid. J. Immunol. 155: 5449-5454.

26. Liu, Z., L.A. Diaz, L. Haas, and G.J. Giudice. 1992. CDNA cloning of a novel human ubiquitin carrier protein. An antigenic domain specifically recognized by endemic pemphigus foliaceus autoantibodies is encoded in a secondary reading frame of this human epidermal transcript. J. Biol. Chem. 267:1582915835.

27. Vila, L.M., H.M. Haftel, H.S. Park, M.-S. Lin, N.C. Romzek, S.M. Hanash, and J. Holoshitz. 1995. Expansion of mycobacterium-reactive $\gamma \delta \mathrm{T}$ cells by a subset of memory helper T cells. Infect. Immunol. 63:1211-1217.

28. Indiveri, F., J. Huddlestone, M.A. Pellegrino, and S. Ferrone. 1980. Iso- 
lation of human T lymphocytes: comparison between wool filtration and rosetting with neuraminidase (VCN) and 2-aminoethylisothiouronium bromide (AET)-treated sheep red blood cells. J. Immunol. Methods. 34:107-115.

29. Miltenyi, S., W. Muller, W. Wiechel, and A. Radbruch. 1989. High gradient magnetic cell separation with MACS. Cytometry. 11:231-238.

30. Taswell, C. 1981. Limiting dilution assays for the determination of immuno-competent cell frequencies. I. Data analysis. J. Immunol. 126:1614-1619.

31. Ohlin, M., L. Danielsson, R. Carlsson, and A.K. Borrebaeck. 1989. The effect of leucyl-leucine methyl ester on proliferation and Ig secretion of EBVtransformed human B lymphocytes. Immunology. 66:485-490.

32. Del Prete, G., M. De Carli, F. Almerigogna, C.K. Daniel, M.M. D'Elios, G. Zancuoghi, F. Vinante, G. Pizzolo, and S. Romagnani. 1995. Preferential expression of $\mathrm{CD} 30$ by human CD4+ T cells producing Th2-type cytokines. FASEB (Fed. Am. Soc. Exp. Biol.) J. 9:81-86.

33. Chen, Y.-W., M.-S. Lin, and K.A. Vora. 1992. B cell differentiation. I. Development and functional analysis of murine B cells immortalized by a recombinant retrovirus. Int. Immunol. 4:1293-1302.

34. Fernandez-Vina, M.A., X Gao, M.E Moraes, J.R Moraes, I Salatie, S. Miller, J. Tsai, Y.P. Sun, Z. Layrisse, E. Gazi, et al. 1991. Alleles at four HLA class II loci determined by oligonucleotide hybridization and their associations in five ethnic groups. Immunogenetics. 34:299-312.

35. Fernandez-Vina, M.A., M. Falco, M. Cerna, E. Raimond, and P. Stastny. 1994. DQA1*03 subtypes have different associations with DRB1 and DQB1 alleles. Hum. Immunol. 39:290-298.

36. Lehmann, P.V., T. Forsthuber, A. Miller, and E.E. Sercarz. 1992. Spreading of T-cell autoimmunity to cryptic determinants of an autoantigen. Nature (Lond.). 358:155-157.

37. Lehmann, P.V., E.E. Sercarz, T. Forsthuber, C.M. Dayan, and G. Gammon. 1993. Determinant spreading and the dynamics of the autoimmune T-cell repertoire. Immunol. Today. 14:203-208.

38. Kaufman, D.L., M. Clare-Salzler, J. Tian, T. Forsthuber, G.S. Ting, P. Robinson, M.A. Atkinson, E.E. Sercarz, A.J. Tobin, and P.V. Lehmann. 1993. Spontaneous loss of T-cell tolerance to glutamic acid decarboxylase in murine insulin-dependent diabetes. Nature (Lond.). 366:69-72.

39. Wucherpfennig, K.W., B. Yu, K. Bhol, D.S. Monos, E. Argyris, R.W. Karr, A.R. Ahmed, and J.L. Strominger. 1995. Structural basis for major histocompatibility complex (MHC)-linked susceptibility to autoimmunity: charged residues of a single MHC binding pocket confer selective presentation of selfpeptides in pemphigus vulgaris. Proc. Natl. Acad. Sci. USA. 92:11935-11939.

40. Ahmed, A.R., E.J. Yunis, K. Khatri, R. Wagner, G. Notani, Z. Awdeh, and C.A. Apler. 1990. Major histocompatibility complex haplotype studies in Ashkenazi Jewish patients with pemphigus vulgaris. Proc. Natl. Acad. Sci. USA. 87:7658-7662.

41. Ahmed, A.R., R. Wagner, K. Khatri, G. Notani, Z. Awdeh, C.A. Apler, and E.J. Yunis. 1991. Major histocompatibility complex haplotypes and class II genes in non-Jewish patients with pemphigus vulgaris. Proc. Natl. Acad. Sci. USA. 88:5056-5060.

42. Matzner, Y., H.A. Erlich, C. Brautbar, A. Sanilevitch, M. Landau, S. Brenner, and A. Friedmann. 1995. Identical HLA class II alleles predispose to drug-triggered and idiopathic pemphigus vulgaris. Acta. Dermato-Venerol. 75: 12-14.

43. Lombardi, M.L., O. Mercuro, G. Tecame, C. Fusco, V. Ruocco, A. Salerno, G. Pirozzi, and C. Manzo. 1996. Molecular analysis of HLA DRB1 and DQB1 in Italian patients with pemphigus vulgaris. Tissue Antigen. 47:228-230.

44. O'Sullivan, D., T. Arrhenius, J. Sidney, M.-F. Del Guercio, M. Albertson, M. Wall, C. Oseroff, S. Southwood, S.M. Colon, F.C.A. Gaeta, and A. Sette. 1991. On the interaction of promiscuous antigenic peptides with different DR alleles: identification of common structural motifs. J. Immunol. 147:26632669.

45. Chicz, R.M., R.G. Urban, J.C. Gorga, D.A.A. Vignali, W.S. Lane, and J.L. Strominger. 1993. Specificity and promiscuity among naturally processed peptides bound to HLA-DR alleles. J. Exp. Med. 178:764-768.

46. Stern, L.J., J.H. Brown, T.S. Jardetzky, R. Urban, J.L. Strominger, and D.C. Wiley. 1994. Crystal structure of the human class II MHC protein HLA DR complexed with an influenza virus peptide. Nature (Lond.). 368:215-221.

47. Jardetzky, T.S., J.C. Gorga, R. Busch, J. Rothbard, J.L. Strominger, and D.C. Wiley. 1990. Peptide binding to HLA-DR1: a peptide with most residues substituted to alanine retains MHC binding. EMBO (Eur. Mol. Biol. Organ.) J. 9:1797-1803.

48. Busch, R., C.M. Hill, J.D. Hayball, J.R. Lamb, and J.B. Rothbard. 1991. Effect of a natural polymorphism at residue 86 of the HLA-DR $\beta$ chain on peptide binding. J. Immunol. 147:1292-1298.

49. Brown, J.H., T.S. Jardetzky, J.C. Gorga, L.J. Stern, R.G. Urban, J.L. Strominger, and D.C. Wiley. 1993. Three-dimensional structure of the human class II histocompatibility antigen HLA-DR1. Nature (Lond.). 364:33-39.

50. Hertl, M., M. Amagai, K. Ishii, R. Karr, and S.I. Katz. 1996. The HLADR11-restricted T cell response to the extracellular portion (EC1-5) of the pemphigus vulgaris antigen (PVA) is modulated by polymorphisms of the $\beta 1$ chain. J. Invest. Dermatol. 106:813a. (Abstr.)

51. Sanders, V.M., R. Fernadez-Botran, R.L. Coffman, T.R. Mosmann, and E.S. Vitetta. 1988. A single antigen-specific B cell can conjugate to either a type 1 or type 2 helper T cell. Proc. Natl. Acad. Sci. USA. 85:7724-7728.

52. Lin, M.-S., and Y.-W. Chen. 1993. B cell differentiation. II. Isotype potential of a single B cell. Cell. Immunol. 150:343-352.

53. Armitage, R.J., B.M. Macduff, M.K. Spriggs, and W.C. Fanslow. 1993. Human B cell proliferation and Ig secretion induced by recombinant CD40 ligand are modulated by soluble cytokines. J. Immunol. 150:3671-3680. 